\title{
Exposure as Collected Dosing Frequency per Interval
}

National Cancer Institute

\section{Source}

National Cancer Institute. Exposure as Collected Dosing Frequency per Interval. NCI

Thesaurus. Code C117483.

The number of doses administered for the collected exposure per a specific interval. 